\title{
PEMANFAATAN TEKNIK KATA KUNCI UNTUK MENINGKATKAN KEMAMPUAN MENULIS TEKS EKSPOSISI SISWA KELAS X MIPA 5 SMA N 1 PAYANGAN
}

\author{
I Nyoman Trayanjana Putra ${ }^{1}$, Ida Bagus Sutresna², Ida Ayu Made Darmayanti ${ }^{3}$ \\ Jurusan Pendidikan Bahasa dan Sastra Indonesia, Fakultas Bahasa dan Seni \\ Universitas Pendidikan Ganesha \\ Singaraja, Indonesia \\ e-mail: \{trayanjanaputra96@gmail.com, sutresna1956@gmail.com, \\ dayudarmayanti1984@yahoo.com\}@undiksha.ac.id
}

\begin{abstract}
ABSTRAK
Penelitian ini merupakan penelitian tindakan kelas (PTK) yang bertujuan (1) mengetahui langkahlangkah penggunaan teknik kata kunci pada pembelajaran menulis teks eksposisi siswa kelas X MIPA 5 di SMA N 1 Payangan, (2) mengetahui peningkatan keterampilan menulis teks eksposisi siswa SMA N 1 Payangan setelah melaksanakan pembelajaran menulis teks eksposisi dengan menggunakan teknik kata kunci. Subjek penelitian ini adalah guru dan siswa. Guru mata pelajaran bahasa Indonesia di kelas X MIPA 5 bernama Ni Putu Lina Wahyuningsih dan siswa kelas X MIPA 5 yang berjumlah 26 di SMA N 1 Payangan. Objek penelitian ini adalah penggunaan kata kunci untuk meningkatkan kemampuan menulis teks eksposisi di kelas X MIPA 5 SMA N 1 Payangan. Metode pengumpulan data ini adalah metode observasi dan metode tes. Metode observasi digunakan untuk mengumpulkan data langkah-langkah pemanfaatan teknik kata kunci dalam menulis teks eksposisi dan metode tes digunakan untuk mengumpulkan data hasil kemampuan menulis teks eksposisi dengan menggunakan teknik kata kunci. Data penelitian ini dianalisis dengan menggunakan teknik deskriptif kualitatif kuantitatif. Hasil penelitian ini menunjukkan bahwa (1) langkah-langkah penerapan teknik kata kunci, yaitu guru memberikan penjelasan kepada siswa melalui tanya jawab untuk menggali pengetahuan siswa, guru menjelaskan langkah-langkah menulis teks eksposisi menggunakan teknik kata kunci, guru membagikan gambar karikatur sebagai media dalam pelatihan menulis teks eksposisi, dan guru membimbing siswa secara intensif agar dapat menghasilkan tulisan yang baik, (2) hasil peningkatan skor yang diperoleh pada pratindakan yaitu 62,3 dengan kategori cukup. Pada siklus I skor meningkat menjadi 65,6 dengan kategori cukup, dan pada siklus II menjadi 72,6 dengan kategori baik. Dapat disimpulkan bahwa pemanfaatan teknik kata kunci dapat meningkatkan kemampuan menulis teks eksposisi siswa kelas $\mathrm{X}$ MIPA 5 SMA N 1 Payangan.
\end{abstract}

Kata kunci: teknik kata kunci, menulis, teks eksposisi

\begin{abstract}
This study was a classroom action research which aims to (1) know the steps of using keyword technique on learning writing exposition text of X class of MIPA 5 in SMA N 1 Payangan, (2) to know the improvement of writing skill of exposition text of SMA N 1 Payangan after implementing writing expository text using keyword technique. The subjects of this study were teachers and students. The name of Indonesian teacher in X class of MIPA 5 is Ni Putu Lina Wahyuningsih and the total of the students were 26 in SMA N 1 Payangan. The object of this study was the use of keywords to improve the students writing ability in writing exposition text in class X MIPA 5 SMA N 1 Payangan. This method of data collection were observation and test methods. Observational methods were used to collect data on the
\end{abstract}


use of keyword techniques in writing expository texts and test methods used to collect data on the results of the ability to write expositive text using the keyword technique. The data of this study were analyzed by using qualitative descriptive quantitative technique. The results of this study indicate that (1) the steps of application of keyword technique, such as the teacher gives explanations to the students through question and answer to explore the students' knowledge, the teacher explains the steps of writing exposition text using the keyword technique, the teacher distributed the caricature image as the media in training of writing expository text, and teacher guiding students intensively in order to produce good writing, (2) the result of score before treatment was 62,3 with enough category. In the first cycle the score increased to 65.6 with sufficient category, and in cycle II to 72.6 with good category. It can be concluded that the utilization of keyword techniques can improve the ability to write expository text of $X$ grade students of MIPA 5 SMA N 1 Payangan.

Keywords: keyword technique, writing, exposition text

\section{PENDAHULUAN}

Pembelajaran merupakan salah satu upaya yang dilakukan oleh seorang guru di sekolah untuk mengajari peserta didik yang kemudian disebut dengan proses belajar mengajar (PBM). Pembelajaran atau proses belajar mengajar (PBM) akan menyebabkan perubahan perilaku peserta didik dari yang tidak tahu menjadi tahu, tidak bisa menjadi bisa, ataupun dari yang sudah bisa menjadi mahir. Pembelajaran yang berhasil adalah pembelajaran yang menghasilkan peserta didik yang mampu melampaui nilai ketuntasan minimal atau setidak-tidaknya memiliki nilai yang sama dengan nilai ketuntasan minimal.

Proses belajar mengajar (PBM) Bahasa Indonesia di sekolah memiliki empat keterampilan berbahasa yang wajib dikuasai oleh siswa. Masing-masing keterampilan tersebut tentu saja memiliki standar ketuntasan minimal. Keempat keterampilan berbahasa, meliputi menyimak, berbicara, membaca, dan menulis. Keempat keterampilan tersebut saling berkaitan dan mendukung dalam penyelenggaraan belajar-mengajar di kelas. Haris (dalam Wendra, 2006: 7) mengungkapkan empat aspek keterampilan berbahasa, meliputi: a) berbicara adalah keterampilan dalam berkomunikasi sebagai hasil proses belajar kreatif sebagai media untuk memperluas wawasan dan dapat dikembangkan dengan berbagai topik; b) menyimak adalah kesengajaan menangkap rangkaian bunyi-bunyi bahasa yang diucapkan oleh pembicara dengan penuh perhatian dalam upaya memahami maksudnya, menilai isinya, dan menyampaikan tanggapan terhadap maksud yang disampaikan oleh pembicara; c) membaca adalah suatu proses yang bersifat kompleks yang meliputi kegiatan yang bersifat fisik dan mental untuk menghasilkan terkomunikasinya pikiran atau perasaan penulis kepada pembaca; dan d) menulis adalah kemampuan menggunakan bahasa untuk berkomunikasi dengan menggunakan bahasa tulis.

Keempat keterampilan berbahasa yang meliputi menyimak, berbicara, membaca, dan menulis harus dikuasai oleh siswa. Namun, keterampilan menulis diakui oleh siswa kelas $\mathrm{X}$ merupakan keterampilan yang paling sulit karena mengintegrasikan banyak kemampuan berbahasa, seperti penguasaan kosa kata, ejaan, penentuan topik, tema, penyusunan kalimat, hingga penyusunan paragraf. Salah satu keterampilan menulis yang diajarkan di sekolah, khususnya Sekolah Menengah Atas (SMA) adalah keterampilan menulis teks eksposisi. Sesuai dengan silabus kelas X kurikulum 2013 bahwa siswa Sekolah Menengah Atas (SMA) dituntut agar mampu menyusun teks eksposisi dengan memperhatikan isi, struktur, dan kebahasaan. Hal ini tercantum dalam silabus kelas $X$ yang berbunyi "mengonstruksikan teks eksposisi dengan memperhatikan isi (permasalahan, argumen, pengetahuan, dan rekomendasi), struktur, dan unsur kebahasaan". Ada 
beberapa tujuan yang harus dicapai oleh siswa dalam $\mathrm{KI}$ keterampilan menulis kelas $X$, tuntutan silabus pun semakin terlihat pada kolom pembelajaran butir nomor tiga yang menerangkan "peserta didik menyusun teks eksposisi dengan memperhatikan isi (permasalahan, argumen, pengetahuan, dan rekomendasi), struktur, dan kebahasaan". Tuntutan tersebut begitu kompleks maka tidaklah salah apabila keterampilan menulis selalu dianggap sulit oleh sebagian besar siswa kelas $X$. Sekalipun alokasi waktu pembelajaran menulis cukup banyak, yaitu 4x45 menit untuk setiap kompetensi dasar yang ingin dicapai. Hal tersebut tidak membuat siswa mampu menguasai keterampilan menulis dengan baik.

Banyak orang yang dapat menguasai keterampilan berbicara dengan baik, tetapi mengalami kesulitan ketika diminta untuk menuangkan idenya dalam sebuah tulisan. Hal itulah yang juga sering dialami oleh sebagian besar siswa. Bagi sebagian besar siswa, menulis merupakan kegiatan yang sulit untuk dilakukan. Pada umumnya, siswa tidak dapat mengomunikasikan maksudnya lewat tulisan secara baik. Siswa juga menyadari banyak hal yang harus diperhatikan saat membuat sebuah tulisan. Hal tersebut didukung oleh pernyataan T.Hedge (dalam Ghazali, 2013: 293) yang mengemukakan bahwa jika dibandingkan dengan kegiatan berbicara, kegiatan menulis harus memenuhi beberapa syarat yang tidak berlaku bagi kegiatan berbicara agar penulisan itu bisa efektif, yaitu: pengorganisasian yang ketat pada pengembangan ide dan informasi, tingkat akurasi yang tinggi agar tidak ada keraguan makna, penggunaan sarana-sarana tata bahasa yang kompleks agar bisa membuat pembaca terfokus pada penekananpenekanan yang diberikan oleh penulis, pemilihan kosakata, pola tatabahasa, dan struktur kalimat secara saksama agar bisa menciptakan gaya yang sesuai dengan tema dan bagi pembacanya nanti.
Terdapat empat tahapan dalam menulis sesuai yang dikemukakan oleh Sudiana, dkk (2015: 172-175) bahwa proses menulis dibagi menjadi empat tahap, yaitu tahap: (1) pramenulis, (2) perencanaan menulis, (3) penulisan, dan (4) perevisian dan publikasi. Dengan begitu, perlahan-lahan siswa akan mampu menulis dengan baik karena pada hakikatnya, kemampuan menulis harus dilatihkan bukan diceramahkan. Sekalipun keterampilan menulis merupakan keterampilan yang paling sulit, tetapi kurikulum mengharuskan siswa untuk dapat menguasainya. Sementara permasalahan yang muncul sekarang adalah siswa mengalami kesulitan dalam pembelajaran keterampilan menulis teks eksposisi.

Masalah kesulitan belajar dalam pembelajaran menulis pun terlihat pada siswa kelas X MIPA 5 SMA N 1 Payangan. Berdasarkan hasil wawancara dengan guru mata pelajaran bahasa Indonesia kelas $\mathrm{X}$, yaitu $\mathrm{Ni}$ Putu Lina Wahyuningsih, ditemukan bahwa nilai rata-rata keterampilan menulis dari 27 orang siswa adalah 65 sedangkan ketuntasan belajar menulis di SMA ini adalah 70. Siswa yang dikatakan tuntas sebanyak 10 orang, sisanya 17 orang belum tuntas. Hal ini menunjukkan bahwa pembelajaran keterampilan menulis masih jauh dari tujuan yang telah ditargetkan oleh guru.

Menurut hasil observasi dan wawancara peneliti dengan guru bahasa dan sastra Indonesia kelas X MIPA 5 SMA $\mathrm{N} 1$ Payangan, peneliti menemukan berbagai masalah yang muncul sebagai akibat dari rendahnya kompetensi keterampilan menulis siswa. Pembelajaran yang dilakukan oleh guru masih belum maksimal. Hal tersebut dapat dilihat dari cara penyampaian materi ajar yang dilakukan oleh guru yang masih menggunakan metode ceramah dan penugasan. Selain itu, pemberian contoh yang konkret juga masih jarang guru lakukan saat pembelajaran. Guru lebih menekankan pada teori yang harus dikuasai oleh siswa daripada melakukan 
praktik untuk memperdalam pemahaman siswa. Hal tersebut sangat monoton dan kurang bervariasi sehingga mengakibatkan ketidakefektifan suatu pembelajaran menulis di kelas. Agar dapat menulis dengan hasil yang maksimal, siswa perlu diberikan bahan ajar yang menarik dan menyenangkan. Selain permasalahan yang muncul dari pihak guru, masalah umum dari pihak siswa juga banyak terjadi dalam setiap pembelajaran menulis teks eksposisi sesuai dengan kurikulum 2013.

Masalah tersebut terungkap dari hasil wawancara dengan siswa kelas yang diampu oleh ibu Ni Putu Lina Wahyuningsih, yaitu kelas X MIPA 5, antara lain (1) siswa kurang berminat untuk mengikuti proses pembelajaran bahasa Indonesia, (2) kurangnya kompetensi pengetahuan siswa tentang struktur teks eksposisi, (3) kurangnya keterampilan siswa dalam menulis teks eksposisi, (4) siswa sulit menuangkan ide dalam bentuk teks eksposisi, serta (5) kurangnya sikap religius dan sosial siswa dalam mengikuti pembelajaran. Saat pembelajaran menulis teks eksposisi secara tertulis berlangsung, sebagian besar siswa mengalami kesulitan ketika mencari dan menentukan bahan untuk menulis teks eksposisi.

Selama pembelajaran, siswa tidak dihadapkan dengan contoh-contoh yang dapat mereka amati secara dekat sebagai pedoman untuk menulis sehingga mereka kesulitan untuk menyusun bahan menulis teks eksposisi. Selain itu, masih banyak siswa yang mengalami kesalahan dalam menulis teks eksposisi, terutama pada aspek struktur teks eksposisi. Siswa belum mampu merangkai tulisan sesuai dengan struktur teks eksposisi yang terdiri atas pernyataan pendapat (tesis), argumentasi, dan penegasan ulang pendapat. Aspek lain, seperti isi teks, pemilihan kosakata, penyusunan kalimat dalam teks, dan mekanik penulisan sesuai dengan rubrik penilaian pada sistem kurikulum pendidikan tahun 2013, juga belum dikuasai dengan baik oleh siswa. Selain itu, sikap siswa dalam mengikuti pembelajaran menulis teks eksposisi juga tidak sesuai dan kurang baik, seperti mengobrol, tidur, bercanda, dan sebagainya. Siswa juga kurang berpartisipasi dalam kegiatan tanya jawab, diskusi kelompok, kurang bersemangat, dan kurang berkonsentrasi saat pembelajaran berlangsung.

Pembelajaran tersebut menuntut siswa untuk menguasai kompetensi dasar yang telah disebutkan dalam Kurikulum 2013, yaitu peserta didik dapat menyusun teks eksposisi dengan memperhatikan isi (permasalahan, argumen, pengetahuan, dan rekomendasi) dan struktur. Kompetensi dasar tersebut akan dapat tercapai dengan baik apabila siswa telah memenuhi indikator-indikator pembelajaran yang meliputi: (1) mampu mengidentifikasi topik dengan menentukan kata-kata kunci, mengembangkannya menjadi kalimatkalimat sederhana yang mengandung permasalahan, argumen, pengetahuan dan sesuai dengan struktur, (2) mampu mengorganisasi isi tulisan eksposisi sesuai dengan struktur dan pola pengembangan yang isinya bertujuan meyakinkan pembaca dengan menunjukkan fakta-fakta yang dapat mendukung gagasannya, serta (3) mampu menulis eksposisi dengan memperhatikan penggunaan bahasa dan EYD.

Pembelajaran menulis kerapkali menjadi permasalahan bagi siswa hingga orang dewasa. Banyak siswa yang kurang mampu untuk menguasai keterampilan menulis dibandingkan dengan keterampilan berbahasa lainnya sehingga keterampilan menulis muncul dalam pembelajaran sekolah dasar hingga menengah. Menghasilkan sebuah tulisan yang berkualitas memerlukan proses pelatihan yang berkelanjutan. Proses menulis tidak dapat hanya dilatihkan sekali dua kali, namun perlu dilatih secara terus-menerus. Maka dari itu, keterampilan menulis sering disebut sebagai keterampilan yang kompleks karena berkesinambungan dan saling berkaitan dengan keterampilan lainnya, seperti menyimak, berbicara, dan membaca. Penulis berpendapat bahwa 
keterampilan menulis merupakan suatu wadah yang bisa dijadikan oleh siswa sebagai sarana pencurahan gagasan yang dapat meningkatkan kemampuan dan kreativitas siswa. Keberhasilan menulis tidak terlepas dari keempat aspek keterampilan bahasa yang wajib dilatih oleh siswa sejak dini dan didukung oleh kemampuan guru dalam mengembangkan sarana pembelajaran menulis untuk mencapai hasil yang maksimal. Menurut Satini (2016: 164), terampil menulis tidak mudah untuk dicapai oleh seseorang karena seseorang lebih dituntut untuk menyampaikan gagasan sebaik-baiknya dengan menggunakan lambang-lambang bahasa sehingga gagasan tersebut dapat dipahami. Banyak manfaat yang didapat dari kegiatan menulis, seperti memperluas wawasan, mencerdaskan pikiran agar kreatif, serta meningkatkan mutu hidup.

Untuk menulis sebuah karangan yang sederhana pun, secara teknis dituntut memenuhi persyaratan dasar, seperti akan menulis karangan yang rumit. Maka dari itu, dalam menulis karangan sederhana, hendaknya dapat memilih topik, membatasinya, mengembangkan gagasan, menyajikannya dalam kalimat dan paragraf yang tersusun secara logis dan sebagainya. Menyadari adanya kesulitan belajar pada siswa maka kesulitan itu perlu untuk diteliti. Agar dapat diketahui secara pasti hal-hal yang menjadi kesulitan bagi siswa, perlu dilakukan diagnosis. Dengan melakukan diagnosis, dapat ditentukan tindak lanjut yang bisa dilakukan untuk mengatasi kesulitan belajar tersebut. Permasalahan yang ditemukan di SMA N 1 Payangan adalah kesulitan siswa dalam menulis teks eksposisi.

Anggapan ketidakmudahan dalam menulis teks eksposisi berangkat dari ketidaktepatan teknik yang diterapkan oleh guru dalam proses belajar mengajar. Terkait dengan hal tersebut, peneliti menawarkan teknik kata kunci yang bisa diterapkan dalam pembelajaran menulis teks eksposisi. Teknik pembelajaran kata kunci termasuk salah satu teknik pembelajaran kosakata (Suyatno dalam Syarif, 2011: 48). Saat pembelajaran menulis teks eksposisi, teknik pancingan kata kunci diterapkan dengan cara guru memancing siswa untuk menentukan katakata kunci sesuai dengan topik yang terkandung dalam gambar karikatur. Pancingan kata ini memacu kreativitas dan mendorong siswa dalam menentukan pilihan kata yang tepat serta memudahkan siswa untuk mengungkapkan argumenargumennya. Setelah itu, siswa dapat mengembangkan kata-kata kunci menjadi kalimat berproposisi dan menulis teks eksposisi berdasarkan gagasan dan faktafakta.

Sebelum penelitian ini direncanakan, ditemukan hasil penelitian yang juga meneliti mengenai diagnosis kesulitan belajar dalam pembelajaran Bahasa Indonesia. Penelitian tersebut dilakukan oleh Syarif (2011) dengan judul Peningkatan Keterampilan Menulis Argumentasi melalui Media Gambar Karikatur Teknik Pancingan Kata Kunci pada Siswa Kelas X.1 Ma Al Hadi Mranggen Demak. Penelitian ini menganalisis faktor penyebab kesulitan belajar keterampilan menulis teks argumentasi dengan teknik dan media yang digunakan oleh guru untuk mengatasinya. Penelitian kedua dilakukan oleh Oktavia (2015) dengan judul Peningkatan Keterampilan Menulis Teks Eksposisi melalui Model Investigasi Kelompok dengan Media Berita dalam Surat Kabar pada Siswa Kelas X-4 TKJ SMK NU Ungaran Kabupaten Semarang Tahun Pelajaran 2014/2015. Penelitian ini menganalisis peningkatan keterampilan menulis teks eksposisi dengan menggunakan media surat kabar. Penelitian ketiga dilakukan oleh Debora Siregar (2013) dengan judul Pengaruh Penggunaan Metode Pancingan Kata Kunci terhadap Kemampuan Menulis Puisi Siswa Kelas VII SMP Negeri 1 Sigumpar Tahun Pembelajaran 2012/2013. Penelitian Debora ini menganalisis metode pancingan 
kata kunci dalam pembelajaran menulis puisi untuk memperoleh hasil yang maksimal. Dari ketiga penelitian yang ada, terlihat perbedaan dengan penelitian yang dirancang oleh peneliti. Maka dari itu, perlu dilakukan penelitian untuk mengkaji permasalahan yang dibahas.

Dari latar belakang tersebut, guru sebaiknya lebih selektif dan cerdas dalam memilih bahan ajar, media pembelajaran, serta teknik pembelajaran yang bervariasi. Seorang guru dituntut untuk menguasai keterampilan berbahasa dalam mengajar dan guru juga harus mampu mengelola kelas, memanfaatkan bahan ajar, serta menerapkan teknik pembelajaran yang tepat agar hasil akhir pembelajaran sesuai dengan yang diharapkan. Penggunaan teknik yang baik dalam pembelajaran akan membangkitkan ketertarikan siswa dalam mengikuti pembelajaran, khususnya pembelajaran bahasa dan sastra Indonesia. Selain penggunaan media, guru juga dapat menerapkan teknik yang mendukung pembelajaran. Dengan demikian, materi yang diajarkan lebih mudah dikuasai oleh siswa. Penelitian ini merupakan salah satu alternatif untuk mengatasi masalah yang muncul dalam pembelajaran menulis teks eksposisi. Selain itu, penelitian ini juga diharapkan mampu memperbaiki kondisi yang ada dengan menerapkan teknik kata kunci. Melalui teknik kata kunci, diharapkan dapat tercipta situasi pembelajaran yang menarik, santai, dan menyenangkan sehingga dapat mengurangi rasa jenuh siswa dalam pembelajaran menulis teks eksposisi. Peneliti beranggapan teknik kata kunci sangat cocok diterapkan dalam pembelajaran menulis teks eksposisi. Pemanfaatan teknik kata kunci dapat meningkatkan minat siswa dan mengatasi kesulitan yang dialami oleh siswa dalam menuangkan ide, gagasan, dan argumenargumennya.

(1)

Tujuan penelitian ini adalah untuk mengetahui langkah-langkah pembelajaran dengan menggunakan teknik kata kunci pada pembelajaran menulis teks eksposisi siswa kelas X MIPA 5 di SMA N 1
Payangan, (2) mengetahui peningkatan kemampuan menulis teks eksposisi siswa kelas X MIPA 5 di SMA N 1 Payangan setelah melaksanakan pembelajaran menulis teks eksposisi dengan menggunakan teknik kata kunci.

Manfaat hasil penelitian ini diharapkan mampu memberikan manfaat bagi pihak-pihak tertentu secara praktis. Secara praktis, hasil penelitian ini diharapkan dapat memberikan manfaat bagi siswa, guru, dan peneliti lain. Manfaat yang dimaksud sebagai berikut (1) bagi siswa, teknik dalam penelitian ini dapat dijadikan cara yang baru untuk meningkatkan hasil belajar di sekolah. Hal ini akan berdampak pada peningkatan hasil belajar siswa, yaitu memperoleh pengalaman belajar yang baru sehingga diharapkan adanya peningkatan dalam kemampuan menulis, tepatnya dalam menulis teks eksposisi, (2) bagi guru, dapat digunakan atau dijadikan acuan untuk mengatasi kesulitan dalam pembelajaran menulis sebagai alternatif untuk mengembangkan pendekatan, metode, dan teknik pengajaran bahasa Indonesia serta menciptakan kegiatan belajar yang menarik. Memberikan masukan kepada guru bahwa penggunaan teknik kata kunci dapat digunakan sebagai variasi pembelajaran menulis dan menambah wawasan serta pengetahuan terhadap penggunaan media dalam pembelajaran menulis, dan (c) bagi peneliti lain, hasil penelitian ini dapat dijadikan bahan untuk penelitian masalah lain yang sejenis dengan penelitian ini. Peneliti lain bisa menemukan masalah lain yang belum dibahas dalam penelitian ini.

\section{METODE PENELITIAN}

Rancangan penelitian yang digunakan dalam penelitian ini adalah rancangan penelitian tindakan kelas. Wendra (2014: 32) menyatakan rancangan penelitian merupakan strategi mengatur 
latar (setting) penelitian agar peneliti memperoleh data yang tepat/valid sesuai dengan karakteristik variabel dan tujuan penelitian. Penelitian tindakan kelas merupakan penelitian yang secara kolaboratif antara peneliti, guru, dan pihak sekolah.

Subjek dalam penelitian ini adalah guru dan siswa. Guru mata pelajaran bahasa Indonesia di kelas X MIPA 5 bernama Ni Putu Lina Wahyuningsih dan siswa kelas X MIPA 5 yang berjumlah 26 orang di SMA N 1 Payangan. Dipilinnya Ni Putu Lina Wahyuningsih sebagai subjek penelitian karena beliau dalam mengajar kurang menerapkan metode pembelajaran yang inovatif dan cenderung menggunakan metode ceramah dan penugasan dalam pelajaran bahasa Indonesia. Siswa kelas X MIPA 5 dipilih sebagai subjek penelitian karena kemampuan menulis teks eksposisinya masih kurang. Hal tersebut dapat dilihat dari skor yang diperoleh siswa masih di bawah KKM, padahal kriteria ketuntasan minimal (KKM) adalah 70.

Objek penelitian merupakan hal yang dikaji dalam penelitian tersebut. Objek dalam penelitian ini adalah penggunaan kata kunci untuk meningkatkan kemampuan menulis teks eksposisi di kelas X MIPA 5 SMA N 1 Payangan.

Data dikumpulkan oleh peneliti menggunakan metode observasi dan metode tes. Pertama, metode observasi digunakan untuk mengetahui langkahlangkah pemanfaatan teknik kata kunci dalam menulis teks eksposisi. Kedua, peneliti menggunakan metode tes untuk mengetahui peningkatan hasil kemampuan menulis teks eksposisi dengan memanfaatkan teknik kata kunci.

Adapun teknik yang digunakan dalam menganalisis data adalah teknik analisis data deskriptif kualitatif kuantitatif. Analisis data deskriptif kualitatif adalah teknik analisis data yang digunakan dengan cara menggambarkan data atau fenomena secara umum untuk dicari simpulannya. Deskripstif kualitatif digunakan untuk menganalisis data mengenai langkah-langkah pembelajaran menulis teks eksposisi dengan teknik kata kunci. Deskriptif kuantitatif digunakan untuk menganalisis data hasil penilaian kemampuan menulis teks eksposisi dengan memanfaatkan teknik kata kunci berupa nilai tes individu.

Penentuan kriteria ketuntasan minimal disesuaikan dengan standar minimal yang digunakan di tempat penelitian yaitu SMA N 1 Payangan. Apabila $75 \%$ dari seluruh siswa sudah memenuhi kriteria ketuntasan yang ditetapkan oleh sekolah dengan nilai $70 \mathrm{ke}$ atas atau skor rata-rata kelas melebihi KKM yang dirancang oleh sekolah tersebut, maka penelitian dapat dihentikan.

\section{HASIL DAN PEMBAHASAN}

Setelah dilakukan penelitian mengenai pemanfaatan teknik kata kunci untuk meningkatkan kemampuan menulis teks eksposisi siswa kelas X MIPA 5 SMA $\mathrm{N} 1$ Payangangan dapat diketahui sebagai berikut.

Berdasarkan hasil observasi yang dilakukan, dapat dikatakan bahwa langkahlangkah pelaksanaan pembelajaran yang dilakukan sudah tergolong baik/bagus. Hal ini dapat dilihat dari penilaian yang diberikan peneliti atau observer saat mengamati guru mengajar.

Pada tindakan siklus I yang dilaksanakan dalam dua kali pertemuan, ada beberapa aspek yang dinilai, dari 20 aspek yang harus dilakukan guru, hanya 3 (tiga) aspek yang tidak terlaksana berdasarkan rencana yang telah disusun sebelumnya. Ketiga aspek tersebut, yaitu (1) guru tidak mengecek kesiapan siswa. (2) guru tidak menyimpulkan dan memberikan umpan balik atau penguatan terhadap unjuk kerja siswa. (3) guru tidak melakukan refleksi dengan menanyakan ke 
siswa hambatan yang dihadapi dalam menulis teks eksposisi

Hasil tes kemampuan menulis teks eksposisi pada siklus 1, yaitu kemampuan siswa kelas $X$ MIPA 5 SMA Negeri 1 Payangan setelah mendapatkan tindakan dari 26 siswa, yang mencapai KKM tetap hanya sebanyak 5 orang siswa. Namun, peningkatan terlihat pada siswa yang mendapat nilai dengan kategori cukup yaitu sebanyak $80,8 \%$ dan siswa yang mendapat nilai dengan kategori kurang sebanyak 0\% atau dengan kata lain tidak ada siswa yang mendapat nilai dengan kategori kurang. Walaupun sudah terjadi peningkatan dengan diperolehnya 21 orang siswa atau sebanyak $80,0 \%$ yang mendapat nilai cukup, hal tersebut belum bisa menuntaskan pembelajaran menulis teks eskposisi karena sebagian besar siswa masih belum bisa mencapai KKM yaitu dengan nilai 70 kategori baik. Nilai rata-rata siswa dalam pembelajaran menulis teks eksposisi setelah mendapat tindakan sudah mengalami peningkatan namun tetap pada kategori cukup, yaitu $65,69 \%$. Dengan nilai rata-rata tersebut maka terjadi peningkatan nilai dari pratindakan sebesar 62,30\% menjadi $65,69 \%$ di siklus 1 . Jika dilihat dari nilai yang ditargetkan pada siklus I yaitu 70 , maka terdapat 21 siswa yang masih berada di bawah nilai rata-rata (nilai KKM). Oleh karena itu, peneliti melanjutkan pada siklus II dengan harapan siswa mampu mencapai nilai 70 .

Rendahnya kemampuan menulis teks eksposisi dikarenakan oleh faktor dari siswa itu sendiri dan dari luar siswa di mana siswa kelas $X$ MIPA 5 SMA Negeri 1 Payangan belum pernah menerima materi menulis teks eksposisi yang menuntut siswa untuk memproduksi teks, sedangkan faktor dari luar berasal dari guru yang belum optimal menerapkan metode atau teknik dengan baik dan intensif.

Hasil kemampuan siklus II mengalami peningkatan dari siklus I dalam pembelajaran menulis teks eksposisi yaitu, kemampuan siswa kelas X MIPA 5 SMA Negeri 1 Payangan setelah mendapatkan tindakan siklus II dari 26 siswa sebanyak 20 orang siswa atau $76,92 \%$ memperoleh kategori baik, sedangkan siswanya berjumlah 6 orang siswa atau 23,08\% memperoleh kategori cukup . Pada siklus II tidak ada siswa yang memperoleh kategori sangat baik, kurang, dan sangat kurang. Meskipun tidak ada yang memperoleh kategori sangat baik, sebagian besar siswa sudah berhasil melampaui KKM yaitu berjumlah 20 orang siswa atau 76,92\%. Dari 26 siswa pada siklus II, 6 siswa memperoleh nilai di bawah KKM yang telah ditentukan dengan kategori cukup. Nilai rata-rata siswa dalam pembelajaran menulis teks eksposisi dengan menggunakan teknik kata kunci setelah mendapat tindakan II berkategori baik, yaitu $72,61 \%$. Dengan nilai rata-rata tersebut maka terjadi peningkatan nilai dari siklus I sebesar 6,92\%.

Pelaksanaan pada siklus II sudah berhasil. Berdasarkan temuan di lapangan guru sudah mempersiapkan materi pembelajaran secara maksimal sesuai dengan cakupan pengetahuan siswa. Guru sudah menjelaskan secara rinci langkahlangkah menulis teks eksposisi dengan menggunakan teknik kata kunci, agar mempermudah siswa dalam menulis teks eksposisi. Sesuai dengan pendapat Hamalik (1993: 4) teknik diartikan sebagai prosedur atau langkah-langkah yang akan ditempuh sesuai dengan tujuan yang hendak dicapai dan materi yang hendak diajarkan.

Pelaksanaan

kegiatan pembelajaran dari pendahuluan, inti, dan penutup yang sudah baik mendukung meningkatkan kemampuan siswa dalam pembelajaran menulis teks eksposisi. Saat pelaksanaan pembelajaran, siswa kelas $X$ MIPA 5 SMA Negeri 1 Payangan merasa senang dan nyaman mengikuti pembelajaran di kelas dengan menggunakan teknik kata kunci. Pembelajaran dengan penggunaan teknik kata kunci membuat siswa merasa dekat dengan topik yang dibahas karena adanya rangsangan visual melalui media gambar 
karikatur sehingga kemauan belajar siswa menjadi meningkat. Maka dari itu, penggunaan media gambar sangat mendukung keberhasilan penerapan teknik kata kunci. Hal ini sejalan dengan pendapat Hamalik, Suyanto (2004: 88) menjelaskan bahwa teknik adalah cara melaksanakan sebuah metode dengan menggunakan alat yang tepat.

Temuan ini sejalan dengan hasil penelitian yang dilakukan oleh Syarif (2011) dengan judul "Peningkatan Keterampilan Menulis Argumentasi melalui Media Gambar Karikatur Teknik Pancingan Kata Kunci pada Siswa Kelas X.1 Ma Al Hadi Miranggen Demak". Syarif menunjukkan bahwa penggunaan teknik kata kuci berdampak baik pada perubahan tingkah laku siswa ke arah positif. Hal tersebut didukung dari hasil penelitiannya terjadi keaktifan dan keantusiasan siswa dalam menerima pembelajaran karena siswa merasa dekat dengan peristiwa yang terjadi dengan melihat gambar karikatur sehingga siswa mudah untuk memvisualisasi dalam pikirannya. Selain itu gambar karikatur memiliki nilai keindahan sehingga siswa tertarik saat mengikuti pembelajaran dengan teknik kata kunci.

Penelitian ini juga sejalan dengan hasil penelitian dari Debora Siregar (2013) dengan judul "Pengaruh Penggunaan Metode Pancingan Kata Kunci terhadap Kemampuan Menulis Puisi Siswa Kelas VII SMP Negeri 1 Sigumpar Tahun Pembelajaran 2012/2013". Hasil penelitian ini menunjukkan bahwa aktivitas belajar siswa dengan menggunakan teknik kata kunci mengalami peningkatan dari segi proses belajar. Di mana dari hasil yang diperoleh siswa sangat antusias, semangat, gembira, dan aktif, dalam mengikuti pembelajaran dan mengerjakan tugas di kelas.

Berdasarkan temuan tersebut, guru bahasa Indonesia di kelas X MIPA 5 SMA Negeri 1 Payangan sudah melaksanakan langkah-langkah pembelajaran dengan baik sesuai dengan perencanaan yang dibuat. Dalam hal ini pada siklus I dan II, guru sudah melaksanakan proses pembelajaran sesuai dengan langkah-langkah penerapan teknik kata kunci walaupun dalam pelaksanaanya masih terjadi kendala. Akan tetapi, kendala tersebut sudah diperbaiki pada perencanaan dan pelaksanaan siklus II, sehingga pelaksanaan pembelajaran dengan menggunakan teknik kata kunci sudah berjalan lancar. Temuan kedua menyangkut peningkatan hasil kemampuan menulis teks eksposisi dengan menggunakan teknik kata kunci. Penerapan teknik kata kunci mampu meningkatkan kemampuan atau keterampilan siswa dalam menulis teks eksposisi. Hal ini terlihat dari rata-rata yang diperoleh oleh siswa. Ratarata skor yang diperoleh siswa pada nilai pratindakan adalah $62,30 \%$ dengan kategori cukup, karena pada pratindakan guru tidak menjelaskan materi secara rinci, guru masih menggunakan metode ceramah dan penugasan dan belum memberikan bimbingan secara intensif pada siswa sehingga siswa kesulitan dalam menulis teks eksposisi.

Perolehan rata-rata skor nilai pada siklus I mengalami peningkatan sebesar $65,69 \%$ dibandingkan dengan pratindakan, karena guru sudah melaksanakan pembelajaran sesuai dengan perencanaan yang dirancang. Peningkatan hasil belajar adalah kemampuan-kemampuan yang dimiliki siswa setelah menerima pengalaman belajarnya. Hasil belajar siswa pada hakikatnya adalah perubahan mencankup bidang kognitif, afektif, dan psikomotor yang berorientasi pada proses belajar mengajar yang di alami siswa (Sudjana, 2005).

Jika dilihat dari hasil tersebut masih banyak siswa yang belum mencapai nilai 70 sesuai dengan KKM yang ditentukan, karena guru belum bisa menerapkan teknik kata kunci secara maksimal. Perencanaan yang dirancang oleh guru belum dilaksanakan dengan maksimal sehingga hasil yang diperoleh siswa kurang maksimal. Oleh karna itu, penelitian ini dilanjutkan pada siklus II dengan perencanaan yang matang untuk memperbaiki kesulitan-kesulitan yang 
dialami oleh siswa. Skor rata-rata yang diperoleh siswa pada siklus II adalah $72,61 \%$ dengan kategori baik dan sudah mencapai kriteria yang ditentukan oleh sekolah. Keberhasilan tercapainya ketuntasan nilai menulis teks eksposisi, karena guru sudah menerapkan langkahlangkah pembelajaran menulis teks eksposisi dengan menggunakan teknik kata kunci. Guru telah berhasil menyamakan persepsi siswa bahwa teknik kata kunci yang digunakan adalah pengadopsian teknik kosa kata seperti yang mereka ketahui ke dalam bentuk teknik kata kunci dengan memanfaatkan gambar karikatur sebagai alat atau media. hal ini sejalan dengan pendapat Suyanto (2004: 89), bahwa teknik pembelajaran kata kunci pada mulanya termasuk teknik pembelajaran kosakata.

Sesuai dengan penelitian yang dilakukan oleh Syarif (2011) yang berjudul "Peningkatan Keterampilan Menulis Argumentasi melalui Media Gambar Karikatur Teknik Pancingan Kata Kunci pada Siswa Kelas X.1 Ma Al Hadi Miranggen Demak", menunujkkan bahwa rata-rata hasil yang diperoleh dalam penelitian ini adalah tercapainya ketuntasan hasil belajar menulis teks argumentasi siswa berkat diterapkannya media gambar karikatur teknik pancingan kata kunci. Peningkatan tersebut terjadi karena guru melakukan perbaikan dengan lebih menekankan penjelasannya pada pembuatan teks argumentasi khususnya mengenai langkah-langkah menulis teks argumentasi dengan menggunakan media gambar karikatur teknik pancingan kata kunci. Selain itu pemberian motivasi pada kegiatan mengamati dalam proses pembelajaran dapat memengaruhi peningkatan hasil belajar siswa. Hal tersebut dibuktikan dari hasil skor yang diperoleh siswa dari pratindakan hingga siklus II , yaitu skor awal diperoleh 54,78\% dengan kategori cukup, siklus I adalah $68,03 \%$ dengan kategori cukup, sedangkan skor rata-rata yang diperoleh siswa pada siklus II adalah $82,00 \%$ dengan kategori baik. Sesuai dengan pendapat Djamarah (2010: 182) menyatakan "motivasi" memegang peranan penting dalam belajar. Seorang siswa tidak akan dapat belajar dengan baik dan tekun jika tidak ada motivasi dalam dirinya. Bahkan, tanpa motivasi, seorang siswa tidak akan melakukan kegiatan belajar". Oleh karena itu, guru selalu memotivasi siswa agar siswa lebih semangat dalam belajar. Motivasi yang diberikan oleh guru sangat penting bagi siswa dalam mencapai hasil belajar yang baik.

Temuan lain yang sejalan mengenai menerapan teknik kata kunci juga dilakukan oleh Debora (2013) yang berjudul "Pengaruh Penggunaan Metode Pancingan Kata Kunci terhadap Kemampuan Menulis Puisi Siswa Kelas VII SMP Negeri 1 Sigumpar Tahun Pembelajaran 2012/2013" menunujkkan bahwa rata-rata hasil yang diperoleh dalam penelitian ini adalah pengaruh dari penggunaan metode pancingan kata kunci terhadap kemampuan menulis puisi siswa. Pengaruh penggunaan metode pancingan kata kunci dapat dilihat dari nilai rata-rata hasil pretest dan posttest siswa. Pada pretest nilai rata-rata siswa pada pembelajaran menulis teks puisi adalah $62,90 \%$, sedangkan pada posttest nilai ratarata siswa pada pembelajaran menulis teks puisi adalah $71,60 \%$.

Selain penelitian yang dilakukan oleh Syarif dan Debora yang menyatakan dengan menggunakan metode atau teknik kata kunci dapat meningkatkan hasil belajar siswa, temuan dari Oktavia (2015) tentang penggunaan media juga dapat meningkatkan hasil belajar siswa. Penelitian yang dilakukan oleh Oktavia berjudul "Peningkatan Keterampilan Menulis Teks Eksposisi melalui Model Investigasi Kelompok dengan Media Berita dalam Surat Kabar pada Siswa Kelas X-4 TKJ SMK NU Ungaran Kabupaten Semarang Tahun Pelajaran 2014/2015" yang menunjukan bahwa penggunaan media berita dalam surat kabar dapat meningkatkan hasil belajar siswa 
khususnya keterampilan menulis teks eksposisi. Hal tersebut dapat dilihat dari peningkatan nilai rata-rata hasil tes menulis teks eksposisi dari sebelum dilakukannya tindakan hingga dilakukan tindakan siklus I kemudian dioptimalkan dalam pelaksanaan siklus II. Nilai rata-rata hasil tes menulis teks eksposisi siswa sebelum dilakukan tindakan adalah $36,33 \%$, nilai rata-rata hasil tes menulis teks eksposisi siswa pada siklus I adalah $60,95 \%$, dan nilai rata-rata hasil tes menulis teks eksposisi siswa pada siklus II adalah $80,77 \%$.

Setelah dilakukan tindakan dengan menggunakan teknik kata kunci pada siklus I, keterampilan menulis teks eksposisi yang masih dalam kategori cukup dan diperbaiki pada siklus II. Dengan demikian, dapat disimpulkan bahwa teknik kata kunci dapat membantu siswa untuk menulis teks eksposisi. Peningkatan hasil belajar siswa dalam menulis teks eksposisi terjadi karena langkah- langkah menulis teks eskposisi dengan menggunakan teknik kata kunci yang diterapkan sudah sesuai dengan landasan teoretis. Pemahaman siswa mengenai tek eksposisi juga sudah sesuai dengan landasan teoretis.

Jadi, dapat dikatakan bahwa penerapan teknik kata kunci dapat meningkatkan aktivitas dan hasil belajar menulis teks eksposisi, karena pada pembelajaran ini nilai siswa meningkat dan mencapai KKM yang telah ditetapkan oleh sekolah. Hal ini dapat dilihat dari peningkatan hasil tes menulis teks eksposisi pada nilai awal siswa terhadap nilai siklus I dan nilai siklus I dibandingkan dengan nilai siklus II. Rata-rata skor nilai siklus II secara klasikla adalah 72,61. Untuk mengatasi permasalahan yang ditemui oleh guru maupun siswa dalam pembelajaran menulis teks eksposisi, guru dapat mengaplikasikan teknik kata kunci. Teknik kata kunci dapat dijadikan salah satu pilihan alternatif dalam upaya meningkatkan kemampuan menulis teks eksposisi.

\section{SIMPULAN DAN SARAN}

Ada beberapa hal yang menjadi simpulan dalam penelitian ini. Pertama Langkah-langkah penerapan teknik kata kunci dapat meningkatkan hasil belajar menulis teks eksposisi siswa kelas X MIPA 5. Kedua, Keterampilan menulis teks eksposisi kelas X MIPA 5 SMA Negeri 1 Payangan setelah menggunakan teknik kata kunci mengalami peningkatan. Hasil yang diperoleh dari pratindakan, siklus I, dan siklus II menunjukkan peningkatan nilai rata-rata yang baik dan mencapai ketuntasan hasil belajar. Hasil pratindakan diperoleh nilai rata-rata sebesar 62.30 dengan kategori cukup. Hasil siklus I diperoleh nilai rata-rata sebesar 65,69 dengan kategori cukup. Hasil siklus II diperoleh nilai rata-rata 72,61 dengan kategori baik. Peningkatan tersebut terjadi karena guru sudah melaksanakan pembelajaran menulis teks eksposisi sesuai dengan langkah-langkah teknik kata kunci. Jadi, teknik kata kunci terbukti dapat meningkatkan pembelajaran menulis teks eksposisi.

Berdasarkan temuan-temuan dalam penelitian ini, peneliti menyampaikan beberapa saran, yaitu (1) guru harus pintar memilih teknik pembelajaran sesuai dengan kebutuhan siswa dan materi pelajaran agar tujuan pembelajaran dapat tercapai dengan hasil yang baik. Penggunaan teknik pembelajaran yang tepat sesuai dengan materi akan memperoleh hasil yang baik, (2) saran untuk sekolah yakni hasil penelitian ini dapat direkomendasikan untuk dibaca oleh guru-guru bahasa Indonesia agar dapat melakukan pembelajaran menulis teks eksposisi yang lebih baik. Selain itu, hasil penelitian ini di rekomendasikan kepada kepala sekolah untuk mengadakan suatu pelatihan mengenai teknik-teknik pembelajaran yang dapat digunakan oleh guru, (3) hasil penelitian ini dapat digunakan sebagai motivasi untuk melakukan penelitian yang berkaitan dengan pembelajaran Bahasa Indonesia di kelas dan mencoba menerapkan teknik kata kunci pada materi lain agar hasilnya dapat menjadi bahan 
konfirmasi terhadap penerapan teknik tersebut.

\section{DAFTAR PUSTAKA}

Debora, Siregar. 2013. Pengaruh Penggunaan Metode Pancingan Kata Kunci Terhadap Kemampuan Menulis Puisi Siswa Kelas VII SMP Negeri 1 Sigumpar. Semarang. Skripsi: Universitas Negeri Semarang.

Djamarah, Bahri dan Aswan Zain. 2006.

Strategi Belajar Mengajar. Jakarta : PT.

Rineka Cipta.

Ghazali, Syukur. 2013. Pemerolehan dan Pembelajaran Bahasa. Malang: Banyumedia Publishing.

Hamalik, Oemar . 1993. Media Pendidikan Cetakan ke VI. Bandung : Citra

Oktavia. 2015. Peningkatan Keterampilan Menulis Teks Eksposisi melalui Model Investigasi Kelompok dengan Media Berita dalam Surat Kabar pada Siswa Kelas X-4 TKJ SMK NU Ungaran. Semarang. Skripsi: Universitas Negeri Semarang.
Satini,Ria. 2016. Kemampuan Menulis Karangan Eksposisi dengan Menggunakan Teknik Mind Map Siswa Kelas X SMA Negeri 14 Padang. Jurnal Penelitian Bahasa dan Sastra Indonesia. V2.i2 (164178).

Sudiana, dkk. 2015. Keterampilan Berbahasa Indonesia: Berorientasi Intergrasi Nasional dan Harmoni Sosial. Singaraja: Universitas Pendidikan Ganesha.

Suyanto. 2004. Teknik Pembelajaran Bahasa dan Sastra Berdasarkan Kurikulum Berbasis Kompetensi. Yogyakarta: Pustaka Pelajar.

Syarif. 2011. Peningkatan Keterampilan Menulis Argumentasi Melalui Media Gambar Karikatur Teknik Pancingan Kata Kunci Pada Siswa Kelas X1 MA AL HADI Miranggen Demak. Semarang: Tidak diterbitkan.

Wendra, I Wayan. 2014. Buku Ajar Penulisan Karya IImiah. Singaraja: Undiksha.

-----. 2006. Keterampilan Berbicara. Singaraja: Undiksha. 


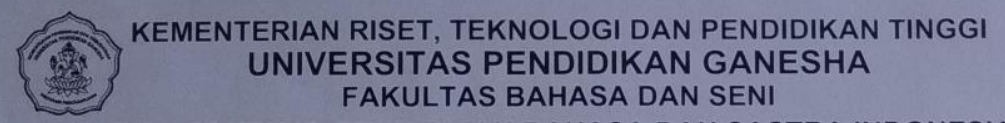

TIM E-JOURNAL PENDIDIKAN BAHASA DAN SASTRA INDONESIA

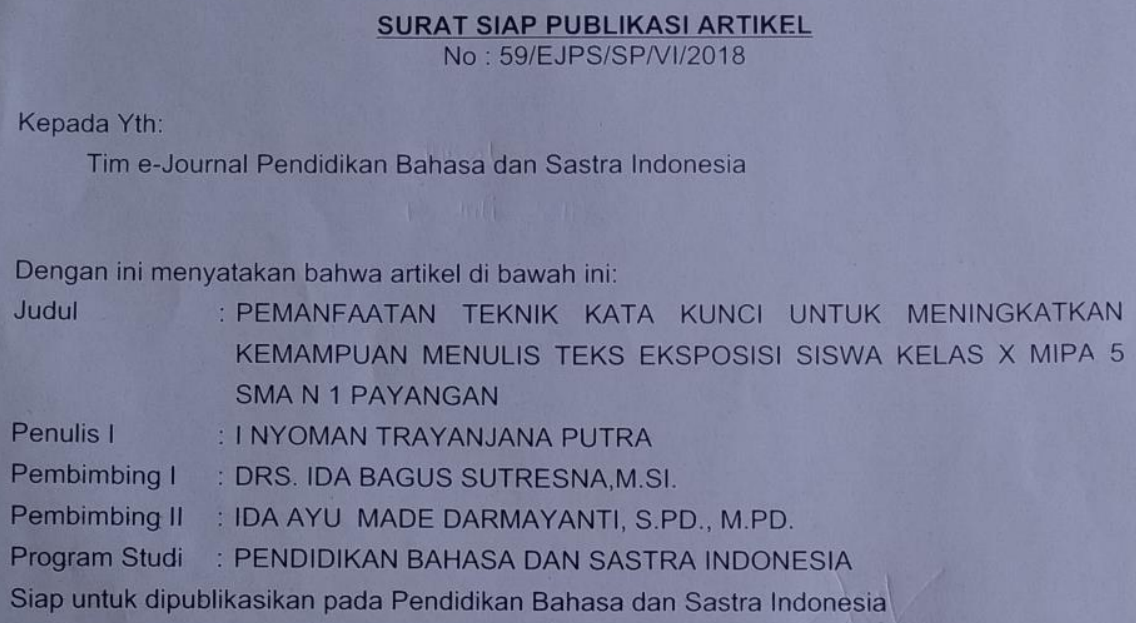

Tim e-Journal Pendidikan Bahasa dan Sastra Indonesia

Dengan ini menyatakan bahwa artikel di bawah ini:

Judul : PEMANFAATAN TEKNIK KATA KUNCI UNTUK MENINGKATKAN KEMAMPUAN MENULIS TEKS EKSPOSISI SISWA KELAS X MIPA 5 SMA N 1 PAYANGAN

Penulis I : INYOMAN TRAYANJANA PUTRA

Pembimbing I : DRS. IDA BAGUS SUTRESNA,M.SI.

Pembimbing II : IDA AYU MADE DARMAYANTI, S.PD., M.PD.

Program Studi : PENDIDIKAN BAHASA DAN SASTRA INDONESIA

Siap untuk dipublikasikan pada Pendidikan Bahasa dan Sastra Indonesia

Demikian surat ini kami sampaikan, atas perhatian dan kerjasamanya diucapkan terima kasih

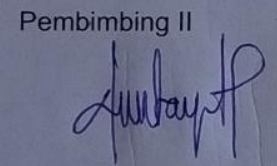

Ida Ayu Made Darmayanti, S.Pd., M.Pd NIP. 198402072008122004
Singaraja,

Pembimbing 1

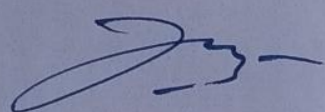

Drs. Ida Bagus Sutresna,M.Si NIP. 195610131983031003 